\title{
Photobiomodulation of oral fibroblasts stimulated with periodontal pathogens
}

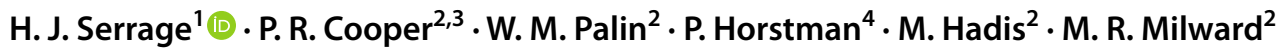

Received: 9 October 2020 / Accepted: 3 May 2021 / Published online: 15 May 2021

(c) The Author(s) 2021

\begin{abstract}
Photobiomodulation (PBM) utilises light energy to treat oral disease, periodontitis. However, there remains inconsistency in the reporting of treatment parameters and a lack of knowledge as to how PBM elicits its molecular effects in vitro. Therefore, this study aimed to establish the potential immunomodulatory effects of blue and near infra-red light irradiation on gingival fibroblasts (GFs), a key cell involved in the pathogenesis of periodontitis. GFs were seeded in 96-well plates in media +/ -Escherichia coli lipopolysaccharide (LPS $1 \mu \mathrm{g} / \mathrm{ml}$ ), or heat-killed Fusobacterium nucleatum (F. nucleatum, 100:1MOI) or Porphyromonas gingivalis (P. gingivalis, 500:1MOI). Cultures were incubated overnight and subsequently irradiated using a bespoke radiometrically calibrated LED array $\left(400-830 \mathrm{~nm}\right.$, irradiance: $24 \mathrm{~mW} / \mathrm{cm}^{2}$ dose: $\left.5.76 \mathrm{~J} / \mathrm{cm}^{2}\right)$. Effects of PBM on mitochondrial activity (3-(4,5-dimethylthiazol-2-yl)-2,5-diphenyltetrazolium bromide (MTT) and adenosine triphosphate (ATP) assays, total reactive oxygen species production (ROS assay) and pro-inflammatory/cytokine response (interleukin-8 (IL-8) and tumour growth factor- $\beta 1$ (TGF $\beta 1$ )) were assessed $24 \mathrm{~h}$ post-irradiation. Data were analysed using one-way ANOVA followed by the Tukey test. Irradiation of untreated (no inflammatory stimulus) cultures at $400 \mathrm{~nm}$ induced $15 \%, 27 \%$ and $13 \%$ increases in MTT, ROS and IL-8 levels, respectively $(p<0.05)$. Exposure with $450 \mathrm{~nm}$ light following application of $P$. gingivalis, $F$. nucleatum or LPS induced significant decreases in TGF $\beta 1$ secretion relative to their bacterially stimulated controls $(p<0.001)$. Following stimulation with $P$. gingivalis, $400 \mathrm{~nm}$ irradiation induced $14 \%$ increases in MTT, respectively, relative to bacteria-stimulated controls $(p<0.05)$. These findings could identify important irradiation parameters to enable management of the hyper-inflammatory response characteristic of periodontitis.
\end{abstract}

Keywords Photobiomodulation $\cdot$ Periodontitis $\cdot$ Fibroblast $\cdot$ Mitochondria $\cdot$ PBM

\section{Introduction}

Photobiomodulation (PBM) is defined as the application of light at $400-1100 \mathrm{~nm}$ to promote tissue healing and reduce inflammation [1]. One area that has gathered considerable interest in recent years is the application of PBM in the management of periodontitis [2]. Periodontitis is a highly

H. J. Serrage

hannah.serrage@bristol.ac.uk

1 Oral Microbiology Unit, Department of Oral and Dental Science, University of Bristol, Bristol BS1 2LY, UK

2 School of Dentistry, University of Birmingham, Birmingham, UK

3 Faculty of Dentistry, Department of Oral Biology, Sir John Walsh Research Institute University of Otago, Dunedin, New Zealand

4 Philips Research, Eindhoven, Netherlands prevalent chronic oral inflammatory disease characterised by the loss of structures surrounding and supporting the tooth. Periodontitis affects $43 \%$ of the UK adult population and costs the National Health Service (NHS) an estimated $£ 2.8$ billion per annum for patient treatment [3]. Periodontitis not only leads to tooth loss but has also been shown to adversely affect masticatory function, quality of life [4] and systemic health [5]. Furthermore, periodontitis and periodontitis-associated pathogens have been associated with the onset of systemic diseases including infective endocarditis [6], Alzheimer's disease [7] and colorectal cancer [8]. New treatments are thus urgently required to manage and treat this prevalent disease.

The key aetiological agent in periodontal disease is the oral biofilm. Oral biofilm formation is characterised by the initial adhesion of primary colonisers to the salivary pellicle. This facilitates coaggregation with bridging species including Fusobacterium nucleatum (F. nucleatum), enabling the 
colonisation by periopathogenic bacterial species including Porphyromonas gingivalis (P. gingivalis) $[9,10]$. Rendering, $F$. nucleatum and $P$. gingivalis key species in oral disease associated biofilm formation. In turn, bacterial stimuli can be recognised by receptors localised on the surface of oral cell types including gingival fibroblasts (GFs) culminating in increased cytokine release, leading to the propagation of inflammation associated with periodontitis $[11,12]$.

GFs are a fundamental cell type in the study of oral disease due to their abundance and their ability to modulate oral inflammation [13]. Healthy GFs also exhibit different responses to stimuli when compared with inflamed GFs, making them a model cell type for elucidating the biomodulatory effects of light [14].

GFs are commonly used to explore the effects of PBM as a model for periodontitis. In particular, near infra-red (NIR) light has been observed to promote cell proliferation [15-17] and decrease markers for inflammation [18-20] from GFs. Comparatively, the effects of blue light have only been reported by relatively few authors, where high doses of blue light $\left(>100 \mathrm{~J} / \mathrm{cm}^{2}\right)$ induce increased oxidative stress $[21,22]$. However, blue light application $(405 \mathrm{~nm})$ was also proven effective as red light $(635 \mathrm{~nm})$ in promoting gingival fibroblast cell proliferation at $25 \mathrm{~J} / \mathrm{cm}^{2}$ [23]. Indicating the possible modulatory capacity of low-dose blue light. The majority of studies evaluate the effects of PBM on GFs following application of a pro-inflammatory stimulus, most commonly lipopolysaccharide (LPS) [18, 19, 24-26]. LPS is a virulence factor located on the surface of gram-negative pathogens including $F$. nucleatum and $P$. gingivalis. However, as species associated with periodontal disease produce a range of virulence factors [27], the biomodulatory effects of PBM in managing inflammation induced by oral biofilm relevant species remain to be elucidated.

The effects of PBM on oral fibroblasts have also been reviewed by Ren et al. [28] and concluded there remain several key issues yet to be addressed. Notably poor experimental design where parameters including wavelength $(\mathrm{nm})$ were incorrectly measured or not reported at all [29], rendering it difficult to draw conclusions regarding the possible benefits of PBM in periodontitis management.

The cellular effects of PBM are also yet to be fully elucidated. Light is proposed to modulate mitochondrial activity via the excitation of complexes of the mitochondrially located electron transport chain (ETC), inducing the production of reactive oxygen species (ROS) and the cells' energy source, adenosine triphosphate (ATP) as a by-product of the progression of the ETC. In turn, ROS induces the activity of downstream targets including nuclear factor kappa-lightchain-enhancer of activated B cells (NFKB) which modulates the transcription of chemokines, cytokines and growth factors [30]. The levels of activation of NFKB have been shown to correlate with interleukin 8 (IL-8) [31]. IL-8 is a chemokine and periodontitis biomarker, produced by GFs. At high concentrations, IL-8 is instrumental in the recruitment of inflammatory cell types involved in periodontal tissue destruction [32,33]. But, at low levels, it is reported to modulate cellular homeostasis [34]. Indeed, a number of authors have established the biomodulatory effects of NIR light on IL-8 secretion from GFs. Indeed, NIR light exposure resulted in significant decreases in IL- 8 secretion from pro-inflammatory stimulus-treated GFs [18, 19, 25, 35-38]. However, as to whether this effect is linked to changes in mitochondrial activity is yet to be elucidated.

Transforming growth factor- $\beta$ (TGF $\beta$ ) signalling is also proposed to be modulated by changes in ROS production. TGF $\beta$ is secreted in its inactive state associated with latencyassociated peptide (LAP). The dissociation of which is proposed to be induced by increases in ROS (caused by PBM), to form active TGF $\beta$, of which there are three mammalian isoforms where TGF $\beta 1$ has been identified as a periodontitis biomarker [39]. PBM has been identified to reduce TGF $\beta 1$ in gingival crevicular fluid (GCF, an inflammatory exudate derived from periodontal tissues) following nonsurgical periodontal treatment [40]. In turn, TGF $\beta$ binds its cell surface receptor TGF $\beta$ RIII, which then transfers TGF $\beta$ to TGF $\beta$ RI and TGF $\beta$ RII leading to downstream effects including angiogenesis and fibrosis. However, light-induced changes in TGF $\beta$ signalling have only been reported by a handful of authors and are yet to be explored in GFs [30].

Using an array we have previously developed and characterised [41], the aim of this study was to further explore the effects of low-dose PBM at wavelengths spanning the visible to NIR spectrum on mitochondrial activity (ROS and ATP assay) and ROS-induced downstream changes on IL-8 and TGF $\beta$ signalling (TGF $\beta 1$ and TGF $\beta R 1$ ). Furthermore, the effects of PBM on GFs were explored under health- and disease-relevant conditions by exposure to periodontopathogens. Our findings aim to not only improve the understanding of the cellular response of GFs to PBM but also identify irradiation parameters for translation to the clinical management of periodontitis. Where, we provide novel evidence of the modulatory effects of low-dose blue light on gingival fibroblasts and its potential efficacy in the management of oral disease.

\section{Materials and methods}

\section{LED array design}

The LED array was designed using CADsoft EAGLE software, in which 60 centrally located $5 \mathrm{~mm}$ epoxy-encased LEDs (Roithner Laserthek, Vienna, Austria) were located within a 96-microwell plate. The array contained ten channels, each emitting different peak wavelengths $(400-830 \mathrm{~nm}$, 
$\mathrm{n}=6)$ and a standardised irradiance value of $24 \mathrm{~mW} / \mathrm{cm}^{2}$. During irradiation, columns 5 and 7 were switched off to act as non-irradiated controls (depicted in Supplementary Fig. 1). Variable resistors were attached to each wavelength channel to enable independent voltage control to ensure uniform irradiance delivery across the array. To ensure concentric alignment of the array with cell cultures and prevention of potential bleed between wavelength channels, a sleeve was created via removal of the clear plastic base of a black 96-well plate (Corning, Sigma-Aldrich, MO, USA). A benchtop power supply (Iso-Tech, IPS-603, UK) was used to power the array. Array design is depicted in Supplementary Fig. 1 and described in detail by Hadis et al. [42].

\section{LED array characterisation}

\section{Spectral characterisation}

A UV-Vis spectrometer (USB400, Ocean Optics, UK) coupled to a $200-\mu \mathrm{m}$ optical fibre and opaline glass CC3 cosine corrector was used to assess emitted spectral irradiance and wavelength values (calibrated to a National Institute of Standards and Technology (NIST) traceable light source (Micropack DH200/Ocean Optics, UK)). Spectral irradiance measurements from each individual LED were recorded utilising OceanView software (Ocean Optics, UK), providing an average emitted spectral irradiance of $\sim 24 \mathrm{~mW} /$ $\mathrm{cm}^{2}$ (Table 1). Acquisition of these measurement facilitated calculation of radiant exposure $\left(\mathrm{J} / \mathrm{cm}^{2}\right.$, energy received per unit area) through multiplication of irradiance output (W/ $\mathrm{cm}^{2}$ ) by irradiation period (Table 1). Detailed experimental procedure and additional characterisation measures are reported by Hadis et al. [42].

Table 1 Details of parameters emitted from our 96-well LED array at each wavelength channel (range: $400-830 \mathrm{~nm})$. Irradiance $\left(\mathrm{mW} / \mathrm{cm}^{2}\right)$ and recorded wavelength $(\mathrm{nm})$ were measured using a UV-Vis spectrometer and beam area $\left(\mathrm{cm}^{2}\right)$ was determined using beam profilometry, in which a 96-well black clear bottom plate was placed above the LED array during measurements to replicate experimental conditions ( $\mathrm{n}=6$ for each wavelength channel). Radiant exposure is also reported

\section{Beam profile}

A charge-coupled device (CCD) camera beam profiler (SP620, Ophir, Spiricon, Jerusalem, Israel) was employed to measure spatial distribution of irradiance. Wavelengths between 400 and $830 \mathrm{~nm}$ were measured through a target screen (N-BK7 ground glass diffuser, Thorlabs, NJ, USA) to ensure reliable indication of the spatial distribution of irradiance at the plane of the adherent cells. A 50-mm closedcircuit television lens (CCTV; Ophir, Spiricon) attached to the camera and focused on the base of each well. Following linear, optical and ambient light correction, images were recorded using BeamGage software. Detailed experimental procedures have been previously reported [42]. Calculated beam area is described in Table 1 and representative beam profile images have been previously reported by Serrage et al. [43].

\section{Biological responses}

\section{Bacterial culture}

Bacterial stocks of Porphyromonas gingivalis ( $P$. gingivalis, ATCC 33,277) and Fusobacterium nucleatum sp. Polymorphum (F. nucleatum, ATCC 10,953) were acquired from the American Type Culture Collection (ATCC, USA) and routinely cultured in $3.7 \%$ w/v Sabouraud Dextrose Broth (OXOID) for $<10$ days under anaerobic conditions $\left(37^{\circ} \mathrm{C}\right.$ ). Following initial culture, suspensions were centrifuged $3 \times$ (Durafuge 100, Precision, Expotech, USA), resuspended in PBS to a working concentration of $1 \times 10^{8} \mathrm{CFU} / \mathrm{ml}$ and heat-inactivated at $80{ }^{\circ} \mathrm{C}$ for $1 \mathrm{~h}$. Viability of heat-inactivated cultures was assessed on fastidious anaerobe agar

for each time interval (30-480 s) and was calculated through multiplication of average irradiance output $\left(\mathrm{W} / \mathrm{cm}^{2}\right)$ with irradiation time $(\mathrm{s})$. Experimental design and setup are described in detail in Serrage et al. [43]. All parameters were determined over a 240-s irradiation period. LED array design and experimental setup is provided in Supplementary Fig. 1

\begin{tabular}{lllllllll}
\hline $\begin{array}{l}\text { Manufacturer } \\
\text { reported wave- } \\
\text { length }(\mathrm{nm})\end{array}$ & $\begin{array}{l}\text { Measured } \\
\text { wavelength } \\
(\mathrm{nm})\end{array}$ & Irradiance $\left(\mathrm{mW} / \mathrm{cm}^{2}\right)$ & Beam area $\left(\mathrm{cm}^{2}\right)$ & \multicolumn{4}{l}{ Radiant exposure $\left(\mathrm{J} / \mathrm{cm}^{2}\right)$} & \\
\cline { 5 - 8 } & & & & $30 \mathrm{~s}$ & $60 \mathrm{~s}$ & $120 \mathrm{~s}$ & $240 \mathrm{~s}$ & $480 \mathrm{~s}$ \\
\hline 400 & $399.68 \pm 1.02$ & $24.14 \pm 1.42$ & $0.32 \pm 0.04$ & 0.72 & 1.45 & 2.9 & 5.79 & 11.59 \\
450 & $446.85 \pm 2.27$ & $25.16 \pm 1.97$ & $0.24 \pm 0.02$ & 0.75 & 1.51 & 3.02 & 6.04 & 12.09 \\
525 & $523.83 \pm 1.23$ & $23.52 \pm 2.81$ & $0.26 \pm 0.02$ & 0.71 & 1.41 & 2.82 & 5.64 & 11.29 \\
660 & $662.24 \pm 0.6$ & $24.56 \pm 1.40$ & $0.32 \pm 0.04$ & 0.74 & 1.47 & 2.95 & 5.89 & 11.79 \\
740 & $735.51 \pm 1.08$ & $22.90 \pm 1.46$ & $0.28 \pm 0.04$ & 0.69 & 1.37 & 2.75 & 5.5 & 10.99 \\
810 & $817.87 \pm 0.78$ & $22.93 \pm 2.35$ & $0.27 \pm 0.02$ & 0.69 & 1.38 & 2.75 & 5.5 & 11.01 \\
830 & $830.03 \pm 2.87$ & $24.29 \pm 3.26$ & $0.25 \pm 0.01$ & 0.73 & 1.49 & 2.92 & 5.83 & 11.66 \\
White & $455.73 \pm 0.33$ & $26.57 \pm 2.53$ & $0.25 \pm 0.01$ & 0.8 & 1.59 & 3.19 & 6.38 & 12.75 \\
Average & & $24.25 \pm 1.22$ & $0.24 \pm 0.02$ & $0.73 \pm 0.04$ & $1.46 \pm 0.07$ & $2.91 \pm 0.15$ & $5.82 \pm 0.29$ & $11.65 \pm 0.58$ \\
\hline
\end{tabular}


(FAA, OXOID). Purity of cultures was also assessed using Gram stain [44] and species-specific polymerase chain reaction (PCR) undergone as previously reported by Takeshita et al. [45]. Suspensions were stored at $-20{ }^{\circ} \mathrm{C}$ until required for experimentation.

\section{Primary human gingival fibroblast (GF) culture and exposure}

GFs were obtained from waste gingival tissue harvested during surgical extraction of impacted third molars in healthy adult subjects and grown from explants (approved by University of Birmingham Ethics Committee, RG_12-020) and isolated as described previously [46]. Details regarding age, sex and ethnicity of gingival fibroblast donors were not disclosed during this study. GF morphology was assessed by light microscopy, in which a characteristic spindle-shaped morphology was observed [47]. Relative expression of vimentin was also evaluated via real-time PCR as described by Liu et al. [46].

GFs (pooled from three individuals, all at passages 5-8) were cultured in monolayers in Dulbecco's modified eagle medium without phenol red (DMEM, Gibco, UK) supplemented with $10 \% \mathrm{v} / \mathrm{v}$ foetal bovine serum (FBS), $1 \%$ $\mathrm{v} / \mathrm{v}$ penicillin/streptomycin (P/S) and 1\% v/v L-glutamine (Sigma-Aldrich, UK). Fibroblasts were seeded into 96-well black clear bottom plates (7000 cells/well) and incubated overnight $\left(37^{\circ} \mathrm{C}, 5 \% \mathrm{CO} 2\right)$. Cultures were then washed $3 \times$ with $\mathrm{PBS}$ and resuspended in DMEM \pm Escherichia coli LPS (026:B6 1-20 $\mu \mathrm{g} / \mathrm{ml}$, Sigma-Aldrich, UK), heatinactivated $F$. nucleatum (10-500:1 multiplicity of infection, MOI) or heat-inactivated $P$. gingivalis (10-500:1 MOI). Concentrations of periodontopathogens applied to GFs were selected to mimic those reported in periodontal pockets [48, 49].

\section{Irradiation of cultures}

At $16 \mathrm{~h}$ following seeding, cell culture plates were removed from the incubator and placed upon a bespoke 96-well LED array [41], in which LEDs were concentrically aligned with wells from above, and the distance between LEDs and the monolayer of adherent cells was fixed at $3 \mathrm{~mm}$. Cultures were irradiated from directly beneath using the LED array for time intervals up to $480 \mathrm{~s}$. Irradiation parameters, including irradiance, beam area and radiant exposure for each time interval at each wavelength are provided in Table 1. The effects of irradiation on media temperature are provided in Supplementary Fig. 2, in which no significant difference between wavelength channels was observed. For highthroughput assessment of parameters on cell metabolic activity, forty-eight culture wells were irradiated simultaneously with one column of LEDs used as non-irradiated controls ( $n=6$, Supplementary Fig. 1). Following the selection of parameters of interest, eighteen culture wells were irradiated simultaneously, and one column of LEDs was used as non-irradiated controls $(n=6)$. For studies examining the effects of PBM following application of a proinflammatory stimulus, one column of LEDs was used as the non-irradiated unstimulated control $(n=6)$ and a second column as the non-irradiated bacterially stimulated control $(n=6)$. All experiments were performed in triplicate. Following irradiation, cultures were incubated until used for further analysis.

\section{Cell metabolic activity assay}

3-(4,5-dimethylthiazol-2-yl)-2,5-diphenyltetrazolium bromide (MTT) assay (Sigma-Aldrich, UK) was utilised to assess changes in cell metabolic activity. MTT is converted to insoluble formazan via mitochondrial enzymes, the formation of which does not correlate with changes in cell proliferation $[50,51]$. The assay was performed as described by Serrage et al. [43].

\section{Adenosine triphosphate (ATP) assay}

A luminescent ATP detection assay was utilised to detect total levels of cellular ATP $24 \mathrm{~h}$ post-irradiation according to the manufacturer's instructions (Luminescent ATP detection assay, Abcam, UK).

\section{Reactive oxygen species (ROS) assay}

ROS formation was assessed using 2', 7'-dichlorodihydrofluorescein diacetate (H2DCFDA) fluorescent probe (Thermo-Fischer Scientific, UK). Free radicals catalyse the conversion of H2DCFDA to its fluorescent bi-marker DCF, enabling quantification of ROS production. At $24 \mathrm{~h}$ postirradiation media was aspirated, cells were washed with PBS and treated with $10 \mu \mathrm{M}$ H2DCFDA and incubated for $1 \mathrm{~h}$ at $37^{\circ} \mathrm{C}$ [52]. Fluorescence was read using a fluorimeter (Twinkle LB 970, Berthold Industries Ltd, Germany, $485 \mathrm{~nm} / 535 \mathrm{~nm}$, excitation/emission respectively).

\section{Enzyme-linked immunosorbent assay (ELISA)}

GF supernatants were assayed for human total interleukin- 8 (IL-8) and transforming growth factor- $\beta 1$ (TGF $\beta 1$ ) by ELISA according to the manufacturer's protocol (Human IL-8/TGF $\beta 1$ ELISA, both R and D systems, Biotechne, MN, USA). 


\section{Reverse transcription-polymerase chain reaction (RT-PCR)}

Following the initial culture of GFs, cells were lysed, and RNA extracted from lysates according to the manufacturer's instructions (RNeasy mini kit, Qiagen, UK). Reverse Transcription (RT) of RNA samples was performed to produce high-quality cDNA samples using a Bioline Tetro cDNA kit (Bioline, UK) according to the manufacturer's guidelines. A primer mix was prepared containing up to $2 \mu \mathrm{l}$ cDNA, $2 \mu \mathrm{l}$ primer (50 pmol), $8.5 \mu \mathrm{l}$ RNase free water (Qiagen, UK) and $12.5 \mu$ l Biomix red (Bioline, UK). The following primers were employed for this study: transforming growth factor- $\beta$ receptor 1 (TGFßR1: Forward: 5'-CGTTACAGTGTTTCT GCCACCT-3', Reverse: 5'-AGACGAAGCACACTGGTC CAGC-3') and Interleukin-8 (IL-8 F: 5' - CGCCTTAGC GCCCACTGCTCCTGT-3', R: 5'- GGGGCGGGACCT CAGCTGCAC-3'). These genes were selected to explore ROS-induced changes in IL-8 and TGF $\beta$ signalling. Conditions for PCR were as follows: $94{ }^{\circ} \mathrm{C}$ for $5 \mathrm{~min}, 30$ cycles of $60{ }^{\circ} \mathrm{C}, 72{ }^{\circ} \mathrm{C}$ and $94{ }^{\circ} \mathrm{C}$ for 1 min each and an extension step at $72{ }^{\circ} \mathrm{C}$ for $10 \mathrm{~min}$. Relative quantities of cDNA were normalised against the housekeeping gene glyceraldehyde3-phosphate dehydrogenase (GAPDH). PCR products were confirmed using SYBR red $(0.01 \% \mathrm{v} / \mathrm{v}$, Invitrogen, UK) containing agarose gel electrophoresis ( $1.5 \% \mathrm{w} / \mathrm{w}$ agarose). Images were captured under Ultraviolet trans-illumination utilising Genesnap software on the G:box imaging system (Syngene, UK). Semi-quantification of PCR bands was undergone using GeneTools (Syngene, UK).

\section{Statistical analysis}

All experiments were performed in triplicate, with $n=6$ replicates per treatment group per experiment. Data was processed utilising Excel software (Microsoft) and analysis performed using SigmaPlot software (Systat Software Inc, UK). All data was analysed using a general linear model (GLM) followed by a one-way ANOVA test followed by a Tukey test to determine significant differences between nonirradiated controls (bacterially stimulated or otherwise) and light irradiation-treated groups $(p<0.05)$.

\section{Results}

\section{The effects of PBM are wavelength- and dose-dependent}

The biphasic effects of PBM (400-830 nm, 0.72-11.52 J/ $\mathrm{cm}^{2}$ ) on non-stimulated GFs using MTT as a marker for mitochondrial activity were evaluated. High-throughput screening of parameters revealed $400 \mathrm{~nm}$ or $450 \mathrm{~nm}$ light at $5.76 \mathrm{~J} / \mathrm{cm}^{2}(240 \mathrm{~s})$ induced $14.6 \%$ and $9.2 \%$ increases in mitochondrial activity relative to the non-irradiated control $(p<0.01$, Fig. 1a) and thus these parameters were selected for further evaluation. A wavelength of $810 \mathrm{~nm}$ and irradiation period of $240 \mathrm{~s}$ were also selected for further study. Whilst no significant increase in MTT was detected at $810 \mathrm{~nm}$, it is frequently used in vitro and therefore findings could be compared with current literature [53, 54].

\section{Blue light modulates markers for mitochondrial activity and inflammation}

The effects of PBM are hypothesised to be associated with mitochondrially induced temporal changes in ATP and ROS production [30, 55]. Exposure to $400 \mathrm{~nm}$ and $450 \mathrm{~nm}$ light induced significant increases in both ROS and ATP production relative to the untreated control $(p<0.05$, Fig. 1b-c).

ROS-induced changes in IL- 8 and TGF $\beta$ signalling were also assessed. Irradiation at $450 \mathrm{~nm}\left(5.76 \mathrm{~J} / \mathrm{cm}^{2}\right)$ induced $75 \%$ increases in both IL-8 gene expression $(p<0.001$, Fig. 1d) relative to the untreated control. Comparatively, $450 \mathrm{~nm}$ light decreased TGF $\beta$-R 1 gene expression $(p<0.001$, Fig. 1e, Supplementary Fig. 3).

\section{Effects of bacterial stimuli on markers for inflammation are dose-dependent}

The minimum dose of bacterial stimuli to induce increases in markers for inflammation (ROS and IL-8) was assessed to mimic the chronic inflammatory phenotype observed in periodontitis [56]. LPS, heat-inactivated $P$. gingivalis or $F$. nucleatum elicited their effects on ROS production and IL-8 secretion in a dose-dependent manner (Fig. 2). A concentration of $1 \mu \mathrm{g} / \mathrm{ml}$ of LPS, a MOI of 100:1 F. nucleatum and a MOI of 500:1 P. gingivalis were thus selected for experimental application. $P$. gingivalis induced significantly lower levels of IL-8 secretion relative to LPS- and $F$. nucleatum-treated GFs $(p<0.001)$. Indeed, comparable concentrations have also been used in the literature, when assessing the effects of bacterial stimuli on inflammation from oral cell types [48, 49, 57].

\section{Bacterial stimulus-induced changes in mitochondrial activity and inflammation are modulated by blue light}

Bacterially stimulated cultures were assessed for the effects of PBM on markers for cell metabolic and mitochondrial activity (MTT, ROS) and inflammatory response (TGF $\beta 1$, IL-8). Cultures treated with LPS or F. nucleatum exhibited a significant increase in MTT $(p<0.0001$, Fig. $3 \mathrm{a}$ i and iii). Interestingly, blue light (400-450 nm, $5.76 \mathrm{~J} / \mathrm{cm}^{2}$ ) further increased levels significantly higher 
Fig. 1 Blue light modulates markers for mitochondrial activity and inflammation. a Highthroughput analysis of various wavelengths (400-830 nm) and irradiation periods (30-240 s) on cell metabolic activity of pooled primary human gingival fibroblasts (B19, B16, B15 samples, $24 \mathrm{~mW} / \mathrm{cm}^{2}, 0.72-5.76 \mathrm{~J} /$ $\left.\mathrm{cm}^{2}, 30-240 \mathrm{~s}\right) 24 \mathrm{~h}$ postirradiation was assessed via MTT assay. The effects of PBM $(400 \mathrm{~nm}, 450 \mathrm{~nm}$ or $810 \mathrm{~nm}$, $5.76 \mathrm{~J} / \mathrm{cm}^{2}, 24 \mathrm{~mW} / \mathrm{cm}^{2}$ ) on markers for mitochondrial activity and inflammation were measured $24 \mathrm{~h}$ post-irradiation. PBM-induced changes in mitochondrial activity were assessed via ROS (b) and ATP (c) assays. Cell lysates were collected, RNA extracted and RT-PCR employed to elucidate PBMinduced changes in IL-8 (d) and TGFßR1 (e) gene expression. Evaluation of PBM on IL-8 (f) and TGF 1 1 (g) secretion was undergone via collection of supernatants and analysis by ELISA. All experiments were performed in triplicate and presented as mean \pm SD. Significance was assessed using one-way ANOVA followed by Tukey test and is indicated by $* * * p<0.001, * * p<0.01$ and ${ }^{*} p<0.05$ relative to the nonirradiated control, where all data is shown as a percentage of the non-irradiated control, where the non-irradiated control was normalised to $0 \%$
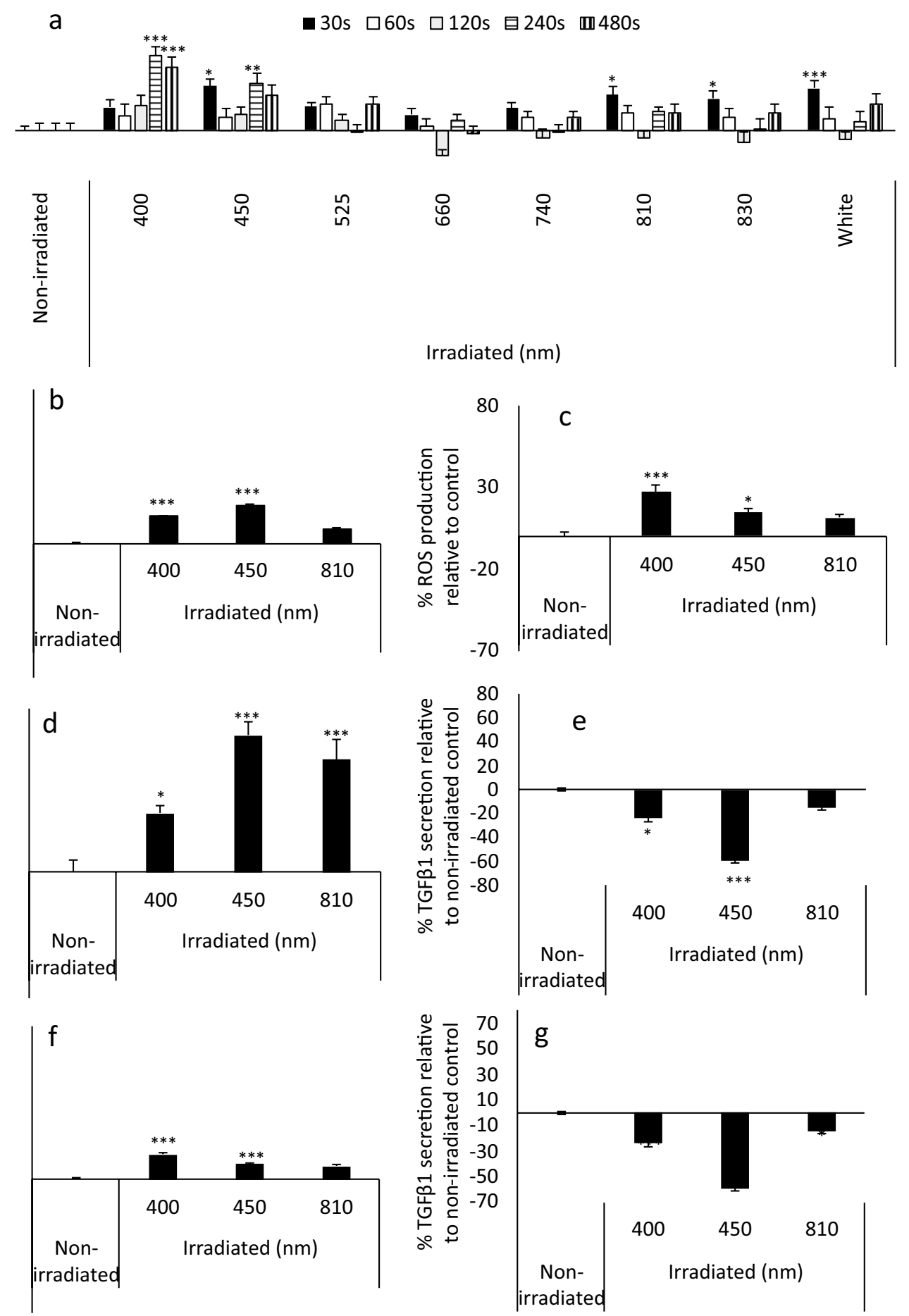

than the respective bacterially treated control $(p<0.0001$, Fig. 3 a i and iii). P. gingivalis-induced decreases $(-29 \%)$ in MTT were alleviated via application of blue light (400-450 nm, $p<0.0001$, Fig. 3a ii). Cell counts were also performed, and data indicated that irradiation of bacterially stimulated cultures induced no significant effect on cell numbers relative to the respective non-irradiated controls (Supplementary Fig. 4). These data indicated that the irradiation conditions applied had no significant effect on cell growth.

Bacterially stimulated cultures (LPS/F. nucleatum/P. gingivalis) treated with $400 \mathrm{~nm}$ light exhibited significant decreases in ROS production relative to their respective bacterially stimulated controls ( $p<0.01$ LPS, $p<0.001 F$. nucleatum and $P$. gingivalis Fig. $3 \mathrm{~b}$ i-iii), to levels comparable with the untreated control. Blue light $(400 \mathrm{~nm})$ 
Fig. 2 LPS, F. nucleatum and $P$. gingivalis modulate markers for inflammation in a dosedependent manner. Following $24 \mathrm{~h}$ incubation, pHGFs (B15, B16 and B19, p5-8) \pm LPS $(1-5 \mu \mathrm{g} / \mathrm{ml}) /$ heat-inactivated $F$. nucleatum (50-500: $1 \mathrm{MOI}) /$ heat-inactivated $P$. gingivalis (50-500:1 MOI) were assayed for ROS production (ROS assay a, c) and IL-8 secretion (ELISA, b, d). All experiments were performed in triplicate and presented as mean $\pm \mathrm{SD}$. Significance was assessed using one-way ANOVA followed by the Tukey test and is indicated by $* * * p<0.001, * * p<0.01$ and $* p<0.05$ relative to the non-irradiated control, where all data is shown as a percentage of the corresponding untreated control, where the untreated control was normalised to $0 \%$
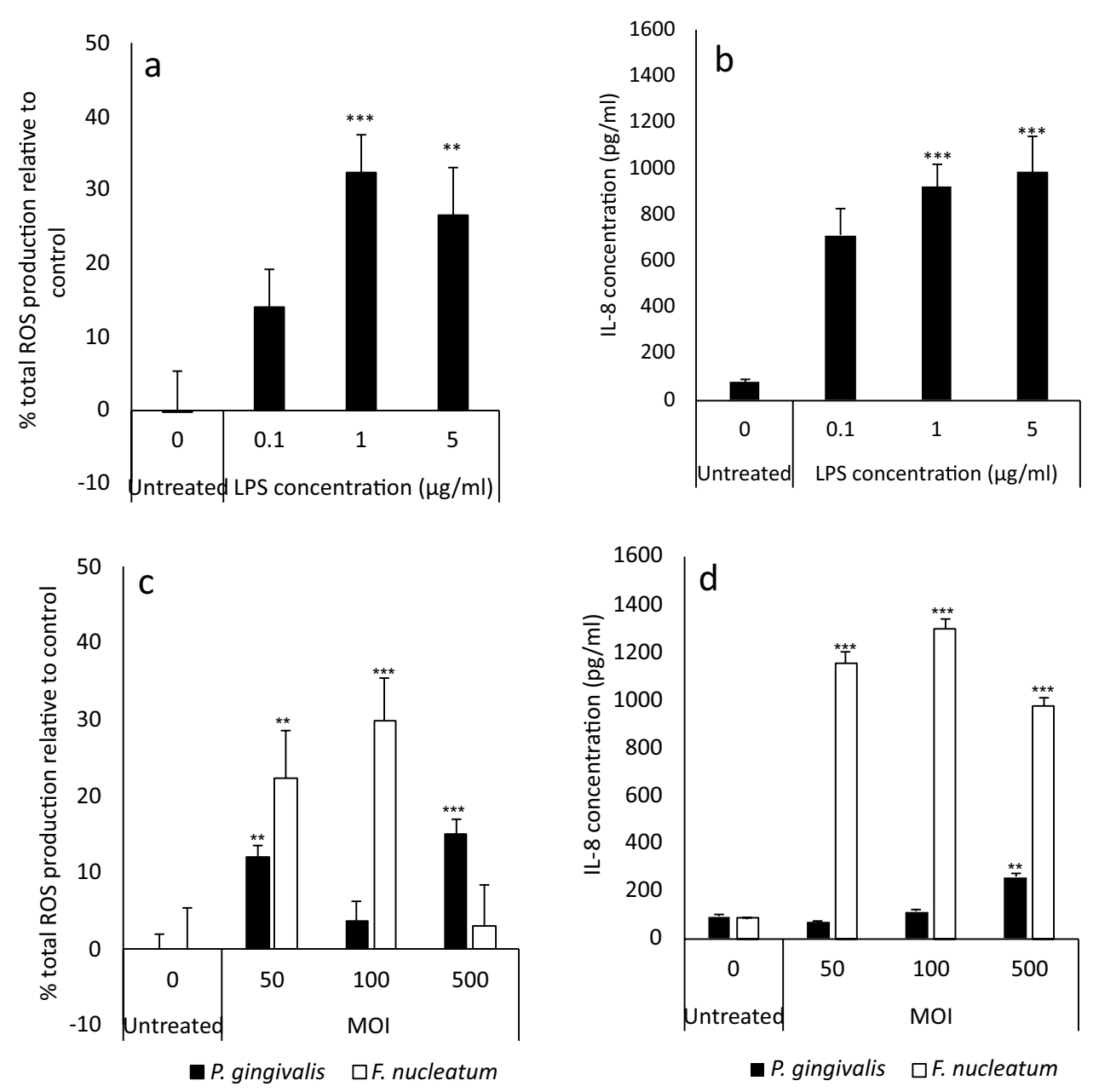

also restored TGF $\beta 1$ secretion to levels comparable to the untreated control for both LPS- and $F$. nucleatum-treated cultures (Fig. 3c i and iii, $p<0.0001$ ).

Analysis of IL-8 secretion by ELISA revealed $400 \mathrm{~nm}$ light application was able to induce significant reductions in IL-8 secretion from LPS $(-40 \%)$ and F. nucleatum (-10\%) stimulated cultures relative to their respective treated controls (Fig. 4a-b, $p<0.001$ ). Application of $400 \mathrm{~nm}$ light induced $36 \%$ increases in IL- 8 secretion relative to the $P$. gingivalis stimulated control respectively (Fig. $4 \mathrm{c}$, $p<0.001)$.

\section{Discussion}

This report provides novel evidence for the biomodulatory effects of blue light on GFs. We demonstrate the use of a high-throughput system for selection of PBM treatment parameters required to induce a response from GFs. In which, a range of parameters were screened simultaneously utilising a novel 96-well LED array. Where, blue light
(400-450 nm) proved most effective in modulating both markers for mitochondrial activity and inflammation.

Blue light is not commonly used in PBM studies due to its proximity to the 'damaging' ultraviolet (UV) band of the electromagnetic spectrum. However, it has been reported that blue light at doses $<55 \mathrm{~J} / \mathrm{cm}^{2}$ can induce beneficial effects including reduced inflammation and improved healing times following oral surgery [30]. Indicating, blue light could prove an effective treatment modality within a narrow therapeutic range.

The direct application of low-dose blue light on GFs has been assessed by relatively few authors, with PBM at $>100 \mathrm{~J} / \mathrm{cm}^{2}$ being required to induce increased mitochondrial ROS production, accelerated oxidative stress and inhibited cell proliferation [21, 22, 58-60]. Comparatively, our report now provides new evidence for the biomodulatory effects of low-dose blue light on GFs at $<10 \mathrm{~J} / \mathrm{cm}^{2}$. Where, parameters employed exert no cytotoxic effects on cell cultures.

Previous reports indicate blue light could excite flavin (complexes I-II) and porphyrin (complex IV) containing complexes of the ETC, inducing increases in mitochondrial 
Fig. 3 PBM modulates bacterially induced changes in markers for cell metabolic activity and inflammation. ppHGFs (B15, B16 and B19, p5-8) \pm LPS $(1 \mu \mathrm{g} / \mathrm{ml}, \mathrm{i}) /$ heat-inactivated $P$. gingivalis (500:1 MOI, ii)/heatinactivated $F$. nucleatum (100:1 MOI, iii) were subsequently treated with PBM (400-810 nm, $5.76 \mathrm{~J} / \mathrm{cm}^{2}, 24 \mathrm{~mW} / \mathrm{cm}^{2}$ ). $\mathrm{PBM}$-induced changes in bacterially stimulated changes in a cell metabolic activity (MTT assay), b ROS production (marker for mitochondrial activity, ROS assay) and c TGF $\beta 1$ secretion (marker for inflammation, ELISA on collected supernatants) were then assessed $24 \mathrm{~h}$ post-irradiation. All experiments were performed in triplicate and presented as mean $\pm S D$. Significance was assessed using one-way ANOVA followed by Tukey's test and results are indicated by $* * * * p<0.0001, * * * p<0.001$, $* * p<0.01$ and $* p<0.05$ relative to the respective nonirradiated controls. All data is shown as a percentage of the non-irradiated control, where the non-irradiated control in each experimental group (LPS, $F$. nucleatum or $P$. gingivalis) was normalised to $0 \%$ a

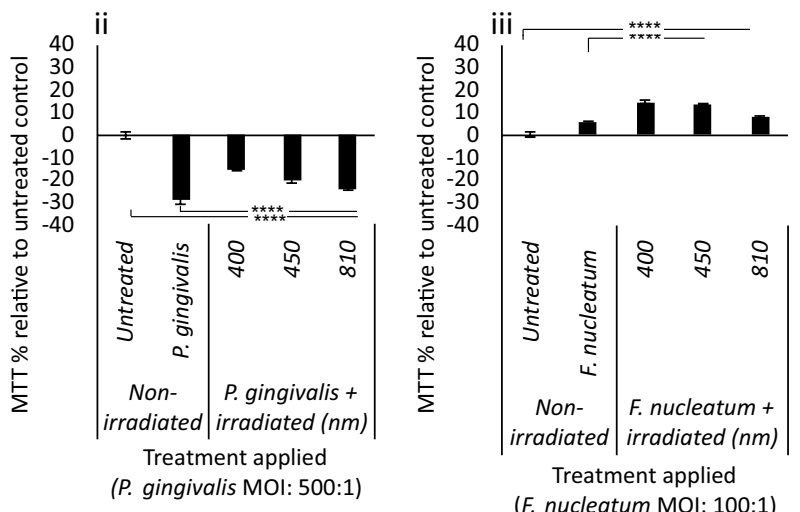

Treatment applied

(F. nucleatum MOI: 100:1)
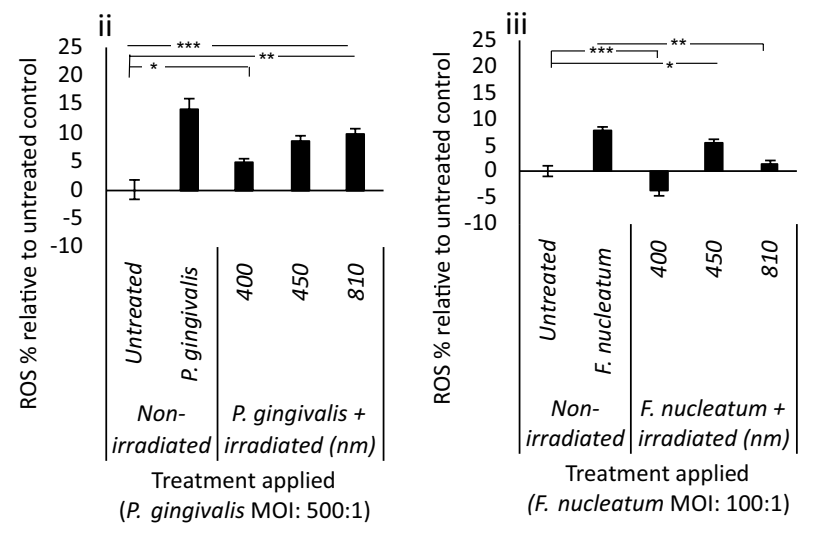

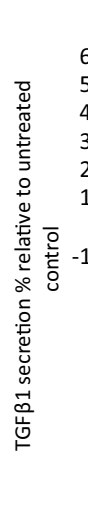

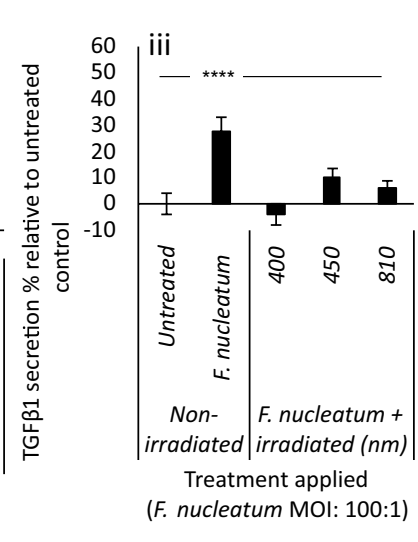

activity and its associated secondary messengers, ROS and ATP [30, 61]. The $400 \mathrm{~nm}$ light induced significant increases in markers for mitochondrial activity (MTT Fig. 1a, ATP and ROS, Fig. 1b-c), which corroborates with findings previously published by our group, wherein blue light modulated the real-time mitochondrial activity of muscle-derived cell types at doses $<10 \mathrm{~J} / \mathrm{cm}^{2}$ [43].

Blue light also exhibited the ability to modulate downstream TGF $\beta$ signalling by reducing TGF $\beta 1$ secretion and TGF $\beta R 1$ gene expression (Fig. $1 \mathrm{~g}$ and e, $p<0.001$ ). The efficacy of blue light inhibiting TGF $\beta$-induced cell differentiation has been previously reported [62]. Differentiated fibroblasts known as myofibroblasts are uncommon in healthy gingival tissue and thus blue light may regulate TGF $\beta$-induced fibroblast differentiation by modulating TGF $\beta 1$ secretion and promoting the autocrine regulation of TGF $\beta R 1$ gene expression [63].

It was also observed that NIR PBM $(810 \mathrm{~nm}, 5.76 \mathrm{~J} /$ $\left.\mathrm{cm}^{2}, p<0.05\right)$ induced significant decreases in TGF $\beta 1$ secretion. Comparatively, literature surrounding the effects of red and NIR PBM on TGF $\beta$ signalling remains conflicting [64-67]. In their review, Mokoena et al. [68] reported authors observed both decreases and increases in TGF $\beta$ signalling following red and NIR PBM. Indicative of the parameter dependent response to PBM and further 
Fig. 4 The effects of PBM on IL-8 secretion are bacterial stimulus-dependent. pHGFs (B15, B16 and B19, p5-8) \pm LPS $(1 \mu \mathrm{g} / \mathrm{ml}, \mathbf{a}) /$ heat-inactivated $F$. nucleatum (100:1 MOI, b)/heat-inactivated $P$. gingivalis (500:1 MOI, c) were subsequently treated with $\pm\left(400-810 \mathrm{~nm}, 5.76 \mathrm{~J} / \mathrm{cm}^{2}\right.$ $\left.24 \mathrm{~mW} / \mathrm{cm}^{2}\right)$. PBM-induced changes in bacterially stimulated changes in IL-8 secretion were then assessed $24 \mathrm{~h}$ postirradiation. All experiments were performed in triplicate and presented as mean \pm SD. Significance was assessed using one-way ANOVA followed by Tukey's test and is indicated by $* * * * p<0.0001 * * * p<0.001$, $* * p<0.01$ and $* p<0.05$ relative to the respective non-irradiated controls. All data is shown as a percentage of the corresponding stimulated control, where the stimulated control in each experimental group (LPS, $F$. nucleatum or $P$. gingivalis) was normalised to $100 \%$
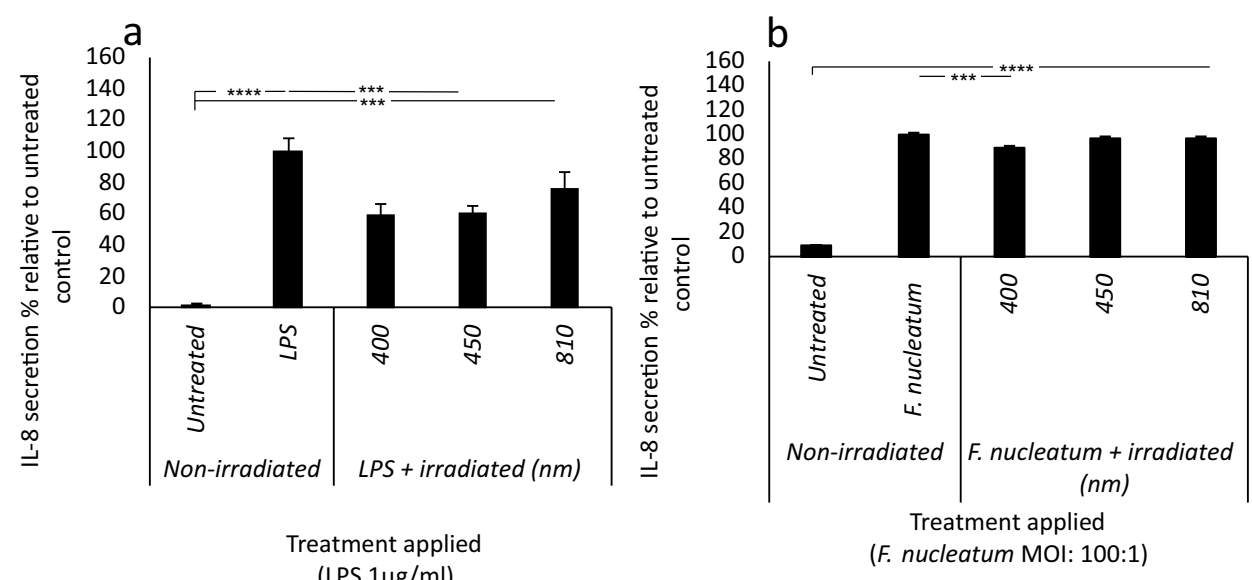

solidifying the requirement for the correct reporting and recording of treatment parameters.

The effects of PBM on periodontal pathogen-stimulated oral fibroblasts were also evaluated. Current literature generally studies the effects of red and NIR PBM on LPSstimulated gingival fibroblasts [18, 24, 25, 28, 36]. Thus, alongside LPS, two species critical in oral biofilm formation and induction of periodontal disease were selected to assess the bacterial stimulus-dependent response to PBM, $F$. nucleatum and $P$. gingivalis.

LPS $(1 \mu \mathrm{g} / \mathrm{ml}), F$. nucleatum (100:1 MOI) and $P$. gingivalis (500:1 MOI) induced significant increases in both ROS and IL- 8 relative to the respective untreated control ( $p<0.001$, Fig. 2). However, the levels of IL-8 secretion induced by $P$. gingivalis were 5- and 3.6-fold lower than those observed for $F$. nucleatum and LPS, which may provide evidence of the possible differing contributions of oral bacterial species to inflammation in vivo.

Changes in mitochondrial function have been shown to influence the rate of formazan formation and thus MTT assay output [69]. LPS and F. nucleatum induced significant increases in MTT relative to the untreated control (Fig. 3a, $p<0.05)$. As LPS has been reported to induce mitochondrial biogenesis [70], it is hypothesised that LPS and F. nucleatum induced increases in mitochondrial function, corroborated by their ability to induce ROS production (Fig. 3b, $p<0.05$ ). Comparatively, $P$. gingivalis decreased cell metabolic activity possibly due to perturbed mitochondrial function [71]. However, application of blue light (400-450 nm, $5.76 \mathrm{~J} / \mathrm{cm}^{2}$ ) induced increased cell metabolic activity of LPS, F. nucleatum- and P. gingivalis-treated cultures (Fig. 3a). This indicated a possible PBM-dependent increase in mitochondrial activity and not cell proliferation, where bacterial stimulation with or without light application had no significant effect on cell number relative to the control (Supplementary Fig. 4).

The effects of PBM on bacterial stimulus-induced changes in ROS production were also evaluated, where the primary source of endogenous ROS is the mitochondria [72]. The $400 \mathrm{~nm}$ light induced significant decreases in ROS production relative to the respective bacterially stimulated controls (Fig. 3b), which may be indicative of a possible feedback loop induced by PBM, leading to the upregulation of antioxidant regulation proteins such as nuclear factor erythroid 2-related factor 2 (Nrf2) [30].

PBM (400 nm) also induced significant decreases in bacterially stimulated TGF $\beta 1$ secretion (Fig. 3c). Following damage to gingival tissue during periodontitis, TGF $\beta$ induced myofibroblast formation can occur, which can lead to delayed wound healing and fibrosis of affected tissue [62]. 
Thus, blue light could be an effective modality in modulating bacterially stimulated TGF $\beta$ signalling in periodontitis.

Concomitantly, $400 \mathrm{~nm}$ light also induced significant reductions in LPS and $F$. nucleatum stimulated increases in IL-8 secretion (Fig. 4) indicating the possible efficacy of blue light in modulating oral inflammation. Indeed, the effects of NIR light in modulating LPS-induced changes in IL-8 secretion have been reported [36]. However, our results do not entirely corroborate these findings. We found that NIR light $(810 \mathrm{~nm})$ had no significant effect on LPS-induced changes in IL-8 secretion. This outcome is possibly due to the different radiant exposure used in this study $(5.76 \mathrm{~J} / \mathrm{cm})$ compared with previous studies which reported modulation of LPS-induced markers for inflammation at $0.5-3 \mathrm{~J} / \mathrm{cm}^{2}[19,36]$.

In comparison, blue and NIR light exacerbated $P$. gingivalis-induced increases in IL-8 secretion. However, levels of IL-8 secretion induced by $P$. gingivalis were significantly lower than those induced by LPS or $F$. nucleatum (Fig. 2). Cytokines such as IL-8 play a critical role in the maintenance of cellular homeostasis and thus are commonplace in healthy gingival tissue [73]. PBM is documented to induce small increases in markers for inflammation from 'healthy tissue' but induces decreases in chronically inflamed tissue [30]. We hypothesise that application of $P$. gingivalis does not induce IL-8 secretion to levels reaching a chronic inflammatory threshold, thus blue light induces further increases, possibly alerting the immune system of the presence of a bacterial stimulus and ensuring effective management of infection.

\section{Conclusion}

We demonstrate novel in vitro evidence of the biomodulatory effects of low-dose blue light. In a model for 'oral health', we observed that blue light (400-450 nm, $5.76 \mathrm{~J} /$ $\mathrm{cm}^{2}$ ) induces small increases in inflammatory markers which could prove beneficial in the maintenance of cellular homeostasis and thus oral health. Comparatively, blue light $\left(400-450 \mathrm{~nm}, 5.76 \mathrm{~J} / \mathrm{cm}^{2}\right)$ induces decreases in IL-8 and ROS from periodontally stimulated GFs, which could prove effective in managing the excessive inflammatory response observed in periodontitis. These findings provide novel evidence of clinically translatable irradiation parameters for the modulation of inflammation associated with oral disease.

Supplementary Information The online version contains supplementary material available at https://doi.org/10.1007/s10103-021-03331-z.

Acknowledgements We would like to thank Dr Cleo White for the kind donation of primary human gingival fibroblasts used in this study.
Author contributions Individual contributions of authors to this article are as follows:

Author 1: Serrage, H.J. contributed to conception, design, acquisition, analysis and interpretation, performed all statistical analyses and drafted and critically revised the manuscript.

Author 2: M.R. Milward contributed to conception and interpretation and critically revised the manuscript.

Author 3: P.R. Cooper contributed to conception and interpretation and critically revised the manuscript.

Author 4: W. Palin contributed to conception and interpretation and critically revised the manuscript.

Author 5: M. Hadis critically revised the manuscript.

Author 6: P. Horstman critically revised the manuscript.

All authors gave their final approval and agree to be accountable for all aspects of the work.

Funding The research in this report is funded as part of an iCASE PHD studentship funded by the Engineering and Physical Sciences Research council (EPSRC) and Philips.

Data availability Data available within the article or its supplementary materials.

\section{Declarations}

Ethics approval Tissue harvested from healthy volunteers for culture of gingival fibroblasts was approved by University of Birmingham Ethics Committee, ethics code: RG_12-020.

Consent for publication All manuscript's copyright ownership is transferred from the authors of this article to Lasers in Medical Science in the event the work is published.

Conflict of interest The authors declare no competing interests.

Open Access This article is licensed under a Creative Commons Attribution 4.0 International License, which permits use, sharing, adaptation, distribution and reproduction in any medium or format, as long as you give appropriate credit to the original author(s) and the source, provide a link to the Creative Commons licence, and indicate if changes were made. The images or other third party material in this article are included in the article's Creative Commons licence, unless indicated otherwise in a credit line to the material. If material is not included in the article's Creative Commons licence and your intended use is not permitted by statutory regulation or exceeds the permitted use, you will need to obtain permission directly from the copyright holder. To view a copy of this licence, visit http://creativecommons.org/licenses/by/4.0/.

\section{References}

1. Mester E, Szende B, Gärtner P (1968) The effect of laser beams on the growth of hair in mice. Radiobiol Radiother 9(5):621-626

2. Carroll JD, Milward MR, Cooper PR, Hadis M, Palin WM (2014) Developments in low level light therapy (LLLT) for dentistry. Dent Mater 30(5):465-475. https://doi.org/10.1016/j.dental.2014. 02.006

3. White DA, Tsakos G, Pitts NB, Fuller E, Douglas GVA, Murray JJ, Steele JG (2012) Adult Dental Health Survey 2009: Common oral health conditions and their impact on the population. Br Dent J 213(11):567-572. https://doi.org/10.1038/sj.bdj.2012.1088 
4. Ferreira MC, Dias-Pereira AC, Branco-de-Almeida LS, Martins CC, Paiva SM (2017) Impact of periodontal disease on quality of life: a systematic review. J Periodontal Res 52(4):651-665. https:// doi.org/10.1111/jre.12436

5. Seitz MW, Listl S, Bartols A, Schubert I, Blaschke K, Haux C, Van Der Zande MM (2019) Current knowledge on correlations between highly prevalent dental conditions and chronic diseases: an umbrella review. Prev Chronic Dis 16:E132. https://doi.org/10. 5888/pcd16.180641

6. Mosailova N, Truong J, Dietrich T, Ashurst J (2019) Streptococcus gordonii: a rare cause of infective endocarditis. Case Rep Infect Dis 2019:7127848. https://doi.org/10.1155/2019/7127848

7. Dominy SS, Lynch C, Ermini F, Benedyk M, Marczyk M, Konradi A, Nguyen M, Haditsch U, Raha D, Griffin C, Holsinger LJ, Arastu-Kapur S, Kaba S, Lee A, Ryder MI, Potempa B, Mydel P, Hellvard A, Adamowicz K, Hasturk H, Walker GD, Reynolds EC, Faull RLM, Curtis MA, Dragunow M, Potempa J (2019) Porphyromonas gingivalis in Alzheimer's disease brains: evidence for disease causation and treatment with small-molecule inhibitors. Sci Adv 5(1):eaau3333. https://doi.org/10.1126/sciadv.aau3333

8. Wu J, Li Q, Fu X (2019) Fusobacterium nucleatum contributes to the carcinogenesis of colorectal cancer by inducing inflammation and suppressing host immunity. Transl Oncol 12(6):846-851. https://doi.org/10.1016/j.tranon.2019.03.003

9. Nobbs AH, Jenkinson HF, Jakubovics NS (2011) Stick to your gums: mechanisms of oral microbial adherence. J Dent Res 90(11):1271-1278. https://doi.org/10.1177/0022034511399096

10. Zenobia C, Hajishengallis G (2015) Porphyromonas gingivalis virulence factors involved in subversion of leukocytes and microbial dysbiosis. Virulence 6(3):236-243. https://doi.org/10.1080/ 21505594.2014.999567

11. Di Benedetto A, Gigante I, Colucci S, Grano M (2013) Periodontal disease: linking the primary inflammation to bone loss. Clin Develop Immunol 2013https://doi.org/10.1155/2013/503754

12. Wang PL, Azuma Y, Shinohara M, Ohura K (2000) Toll-like receptor 4-mediated signal pathway induced by Porphyromonas gingivalis lipopolysaccharide in human gingival fibroblasts. Biochem Biophys Res Commun 273(3):1161-1167. https://doi.org/ 10.1006/bbrc. 2000.3060

13 Williams RC, Skelton AJ, Todryk SM, Rowan AD, Preshaw PM, Taylor JJ (2016) Leptin and pro-inflammatory stimuli synergistically upregulate MMP-1 and MMP-3 secretion in human gingival fibroblasts. PLoS One 11(2):e0148024. https://doi.org/10.1371/ journal.pone.0148024

14. Kang W, Hu Z, Ge S (2016) Healthy and inflamed gingival fibroblasts differ in their inflammatory response to Porphyromonas gingivalis lipopolysaccharide. Inflammation 39(5):1842-1852. https://doi.org/10.1007/s10753-016-0421-4

15. Basso FG, Soares DG, Pansani TN, Cardoso LM, Scheffel DL, de Souza Costa CA, Hebling J (2016) Proliferation, migration, and expression of oral-mucosal-healing-related genes by oral fibroblasts receiving low-level laser therapy after inflammatory cytokines challenge. Lasers Surg Med. https://doi.org/10.1002/ $1 \mathrm{sm} .22553$

16. Park JT, Hong KS (2014) Effect of light-emitting-diode irradiation on the proliferation and migration in human gingival fibroblasts. Tissue Eng Regener Med 12(1):37-42. https://doi.org/10.1007/ s13770-014-9061-7

17. Ogita M, Tsuchida S, Aoki A, Satoh M, Kado S, Sawabe M, Nanbara H, Kobayashi H, Takeuchi Y, Mizutani K, Sasaki Y, Nomura F, Izumi Y (2015) Increased cell proliferation and differential protein expression induced by low-level Er:YAG laser irradiation in human gingival fibroblasts: proteomic analysis. Lasers Med Sci 30(7):1855-1866. https://doi.org/10.1007/s10103-014-1691-4

18. Papadelli A, Kyriakidou K, Kotsakis GA, Pepelassi E, Kallis A, Vrotsos IA, Karoussis IK (2021) Immunomodulatory effects of Nd:YAG (1064 nm) and diode laser $(810 \mathrm{~nm})$ wavelengths to LPS-challenged human gingival fibroblasts. Arch Oral Biol 122:104982. https://doi.org/10.1016/j.archoralbio.2020.104982

19. Basso FG, Pansani TN, Soares DG, Scheffel DL, Bagnato VS, De Souza Costa CA, Hebling J (2015) Biomodulation of inflammatory cytokines related to oral mucositis by low-level laser therapy. Photochem Photobiol 91(4):952-956. https://doi.org/10.1111/php. 12445

20. Lee KD, Chiang MH, Chen PH, Ho ML, Lee HZ, Lee HE, Wang YH (2019) The effect of low-level laser irradiation on hyperglycemia-induced inflammation in human gingival fibroblasts. Lasers Med Sci 34(5):913-920. https://doi.org/10.1007/ s10103-018-2675-6

21. Taoufik K, Mavrogonatou E, Eliades T, Papagiannoulis L, Eliades G, Kletsas D (2008) Effect of blue light on the proliferation of human gingival fibroblasts. Dent Mater 24(7):895-900. https:// doi.org/10.1016/j.dental.2007.10.006

22. Yoshida A, Yoshino F, Makita T, Maehata Y, Higashi K, Miyamoto C, Wada-Takahashi S, Takahashi SS, Takahashi O, Lee MC (2013) Reactive oxygen species production in mitochondria of human gingival fibroblast induced by blue light irradiation. J Photochem Photobiol B 129:1-5. https://doi.org/10.1016/j.jphot obiol.2013.09.003

23. Sterczała B, Grzech-Lésniak K, Michel O, Trzeciakowski W, Dominiak M, Jurczyszyn K (2021) Assessment of human gingival fibroblast proliferation after laser stimulation in vitro using different laser types and wavelengths $(1064,980,635,450$, and $405 \mathrm{~nm}$ )—preliminary report. J Personal Med 11(2):1-17. https:// doi.org/10.3390/jpm11020098

24. Choi H, Lim W, Kim I, Kim J, Ko Y, Kwon H, Kim S, Kabir KM, Li X, Kim O, Lee Y, Kim S, Kim O (2012) Inflammatory cytokines are suppressed by light-emitting diode irradiation of $\mathrm{P}$. gingivalis LPS-treated human gingival fibroblasts: inflammatory cytokine changes by LED irradiation. Lasers Med Sci 27(2):459467. https://doi.org/10.1007/s10103-011-0971-5

25. Kim O, Choi H, Lim W, Kim I, Kim J, Ko Y, Kwon H, Kim S, Ahsan Kabir KM, Li X, Kim O, Lee YJ, Kim S (2012) Inflammatory cytokines are suppressed by light-emitting diode irradiation of P. gingivalis LPS-treated human gingival fibroblasts. Laser Med Sci 27(24):59-467

26. Sakurai Y, Yamaguchi M, Abiko Y (2000) Inhibitory effect of low-level laser irradiation on LPS-stimulated prostaglandin E2 production and cyclooxygenase-2 in human gingival fibroblasts. Eur J Oral Sci 108(1):29-34

27. Graves DT, Jiang Y, Genco C (2000) Periodontal disease: bacterial virulence factors, host response and impact on systemic health. Curr Opin Infect Dis 13(3):227-232

28. Ren C, McGrath C, Jin L, Zhang C, Yang Y (2016) Effect of diode low-level lasers on fibroblasts derived from human periodontal tissue: a systematic review of in vitro studies. Lasers Med Sci 31(7):1493-1510. https://doi.org/10.1007/s10103-016-2026-4

29. Hadis MA, Zainal SA, Holder MJ, Carroll JD, Cooper PR, Milward MR, Palin WM (2016) The dark art of light measurement: accurate radiometry for low-level light therapy. Lasers Med Sci 31(4):789-809. https://doi.org/10.1007/s10103-016-1914-y

30. Serrage H, Heiskanen V, Palin WM, Cooper PR, Milward MR, Hadis M, Hamblin MR (2019) Under the spotlight: mechanisms of photobiomodulation concentrating on blue and green light. Photochem Photobiol Sci 18(8):1877-1909. https://doi.org/10.1039/ c9pp00089e

31. de Matos AG, Ribeiro Junior HL, de Paula BD, Okubo BM, de Sousa JC, Barbosa MC, de Castro MF, Gonçalves RP, Pinheiro RF, Magalhães SMM (2017) Interleukin-8 and nuclear factor kappa B are increased and positively correlated in myelodysplastic syndrome. Med Oncol 34(10):168. https://doi.org/10.1007/ s12032-017-1023-1 
32. Imatani T, Kato T, Okuda K (2001) Production of inflammatory cytokines by human gingival fibroblasts stimulated by cell-surface preparations of Porphyromonas gingivalis. Oral Microbiol Immunol 16(2):65-72. https://doi.org/10.1034/j.1399-302x.2001.01600 2065.x

33. Finoti LS, Nepomuceno R, Pigossi SC, Corbi SC, Secolin R, Scarel-Caminaga RM (2017) Association between interleukin-8 levels and chronic periodontal disease: a PRISMA-compliant systematic review and meta-analysis. Medicine (Baltimore) 96(22):e6932-e6932. https://doi.org/10.1097/MD.0000000000 006932

34. Guo Y, Zang Y, Lv L, Cai F, Qian T, Zhang G, Feng Q (2017) IL-8 promotes proliferation and inhibition of apoptosis via STAT3/AKT/NF- $\kappa$ B pathway in prostate cancer. Mol Med Rep 16(6):9035-9042. https://doi.org/10.3892/mmr.2017.7747

35. Harorli OT, Hatipoglu M, Erin N (2019) Effect of photobiomodulation on secretion of IL- 6 and IL- 8 by human gingival fibroblasts in vitro. Photobiomodul Photomed Laser Surg 37(8):457-464. https://doi.org/10.1089/photob.2018.4589

36. Pansani TN, Basso FG, de Souza Costa CA (2020) In vitro effects of photobiomodulation applied to gingival fibroblasts cultured on titanium and zirconia surfaces and exposed to LPS from Escherichia coli. Lasers Med Sci 35(9):2031-2038. https://doi.org/10. 1007/s10103-020-03062-7

37. Papadelli A, Kyriakidou K, Kotsakis GA, Pepelassi E, Kallis A, Vrotsos IA, Karoussis IK (2021) Immunomodulatory effects of Nd:YAG $(1064 \mathrm{~nm})$ and diode laser $(810 \mathrm{~nm})$ wavelengths to LPS-challenged human gingival fibroblasts. Arch Oral Biol 122. https://doi.org/10.1016/j.archoralbio.2020.104982

38. Pourzarandian A, Watanabe H, Ruwanpura SM, Aoki A, Ishikawa I (2005) Effect of low-level Er:YAG laser irradiation on cultured human gingival fibroblasts. J Periodontol 76(2):187-193. https:// doi.org/10.1902/jop.2005.76.2.187

39. Mize TW, Sundararaj KP, Leite RS, Huang Y (2015) Increased and correlated expression of connective tissue growth factor and transforming growth factor beta 1 in surgically removed periodontal tissues with chronic periodontitis. J Periodontal Res 50(3):315-319. https://doi.org/10.1111/jre.12208

40. Aykol G, Baser U, Maden I, Kazak Z, Onan U, Tanrikulu-Kucuk S, Ademoglu E, Issever H, Yalcin F (2011) The effect of low-level laser therapy as an adjunct to non-surgical periodontal treatment. J Periodontol 82(3):481-488. https://doi.org/10.1902/jop.2010. 100195

41. Hadis MA, Cooper PR, Milward MR, Gorecki PC, Tarte E, Churm J, Palin WM (2017) Development and application of LED arrays for use in phototherapy research. J Biophotonics. https://doi.org/ 10.1002/jbio. 201600273

42. Hadis MA, Cooper PR, Milward MR, Gorecki PC, Tarte E, Churm J, Palin WM (2017) Development and application of LED arrays for use in phototherapy research. J Biophotonics 10(11):1514 1525. https://doi.org/10.1002/jbio.201600273

43. Serrage H, Joanisse S, Cooper PR, Palin W, Hadis M, Darch O, Philp A, Milward MR (2019) Differential responses of myoblasts and myotubes to photobiomodulation are associated with mitochondrial number. J Biophotonics 12(6):e201800411. https://doi. org/10.1002/jbio.201800411

44. Bartholomew JW, Mittwer T (1952) The Gram stain. Bacteriol Rev 16(1):1-29

45. Takeshita M, Haraguchi A, Miura M, Hamachi T, Fukuda T, Sanui T, Takano A, Nishimura F (2017) Antibiotic effects against periodontal bacteria in organ cultured tissue. Clin Exp Dental Res 3(1):5-12. https://doi.org/10.1002/cre2.48

46. Liu X, Wang J, Dong F, Li H, Hou Y (2016) Human gingival fibroblasts induced and differentiated into vascular endotheliallike cells. Dev Growth Differ 58(9):702-713. https://doi.org/10. $1111 /$ dgd.12327
47. Williams RC, Skelton AJ, Todryk SM, Rowan AD, Preshaw PM, Taylor JJ (2016) Leptin and pro-inflammatory stimuli synergistically upregulate MMP-1 and MMP-3 secretion in human gingival fibroblasts. PLoS ONE 11(2):e0148024. https://doi.org/10.1371/ journal.pone. 0148024

48. Abdulkareem AA, Shelton RM, Landini G, Cooper PR, Milward MR (2018) Potential role of periodontal pathogens in compromising epithelial barrier function by inducing epithelial-mesenchymal transition. J Periodontal Res 53(4):565-574. https://doi.org/10. 1111/jre. 12546

49. Dierickx K, Pauwels M, Van Eldere J, Cassiman JJ, Van Steenberghe D, Quirynen M (2002) Viability of cultured periodontal pocket epithelium cells and Porphyromonas gingivalis association. J Clin Periodontol 29(11):987-996. https://doi.org/10.1034/j. 1600-051X.2002.291103.x

50. Sieuwerts AM, Klijn JG, Peters HA, Foekens JA (1995) The MTT tetrazolium salt assay scrutinized: how to use this assay reliably to measure metabolic activity of cell cultures in vitro for the assessment of growth characteristics, IC50-values and cell survival. Eur J Clin Chem Clin Biochem 33(11):813-823

51. Wang P, Henning SM, Heber D (2010) Limitations of MTT and MTS-based assays for measurement of antiproliferative activity of green tea polyphenols. PLoS ONE 5(4):e10202-e10202. https:// doi.org/10.1371/journal.pone.0010202

52. Gomez-Florit M, Monjo M, Ramis JM (2014) Identification of quercitrin as a potential therapeutic agent for periodontal applications. J Periodontol 85(7):966-974. https://doi.org/10.1902/jop. 2014.130438

53. Wang Y, Bai X, Wang Z, Cao J, Dong Y, Dong Y, Chen Y (2017) Various LED wavelengths affected myofiber development and satellite cell proliferation of chick embryos via the IGF-1 signaling pathway. Photochem Photobiol 93(6):1492-1501. https://doi.org/ $10.1111 / \mathrm{php} .12806$

54. Usumez A, Cengiz B, Oztuzcu S, Demir T, Aras MH, Gutknecht $\mathrm{N}$ (2014) Effects of laser irradiation at different wavelengths $(660,810,980$, and $1,064 \mathrm{~nm})$ on mucositis in an animal model of wound healing. Lasers Med Sci 29(6):1807-1813. https://doi. org/10.1007/s10103-013-1336-Z

55. de Freitas LF, Hamblin MR (2016) Proposed mechanisms of photobiomodulation or low-level light therapy. IEEE J Select Top Quantum Electron 22(3):7000417. https://doi.org/10.1109/ JSTQE.2016.2561201

56. Hoare A, Soto C, Rojas-Celis V, Bravo D (2019) Chronic inflammation as a link between periodontitis and carcinogenesis. Mediators Inflamm 2019:1029857. https://doi.org/10.1155/2019/10298 57

57. Milward MR, Chapple IL, Wright HJ, Millard JL, Matthews JB, Cooper PR (2007) Differential activation of NF-kappaB and gene expression in oral epithelial cells by periodontal pathogens. Clin Exp Immunol 148(2):307-324. https://doi.org/10.1111/j.13652249.2007.03342.x

58. Yoshida A, Shiotsu-Ogura Y, Wada-Takahashi S, Takahashi S-s, Toyama T, Yoshino F (2015) Blue light irradiation-induced oxidative stress in vivo via ROS generation in rat gingival tissue. J Photochem Photobiol, B 151:48-53. https://doi.org/10.1016/j. jphotobiol.2015.07.001

59. Yoshino F, Yoshida A (2018) Effects of blue-light irradiation during dental treatment. Jpn Dent Sci Rev 54(4):160-168. https://doi. org/10.1016/j.jdsr.2018.06.002

60. Yoshino F, Yoshida A, Okada E, Okada Y, Maehata Y, Miyamoto C, Kishimoto S, Otsuka T, Nishimura T, Lee MC-i, (2012) Dental resin curing blue light induced oxidative stress with reactive oxygen species production. J Photochem Photobiol, B 114:73-78. https://doi.org/10.1016/j.jphotobiol.2012.05.012

61. Magni G, Banchelli M, Cherchi F, Coppi E, Fraccalvieri M, Rossi M, Tatini F, Pugliese AM, Degl'innocenti DR, Alfieri D, Matteini 
P, Pini R, Pavone FS, Rossi F, (2020) Experimental study on blue light interaction with human keloid-derived fibroblasts. Biomedicines 8(12):1-19. https://doi.org/10.3390/biomedicines8120573

62. Taflinski L, Demir E, Kauczok J, Fuchs PC, Born M, Suschek CV, Oplander C (2014) Blue light inhibits transforming growth factor-beta1-induced myofibroblast differentiation of human dermal fibroblasts. Exp Dermatol 23(4):240-246. https://doi.org/10. 1111/exd.12353

63. Smith PC (2018) Role of myofibroblasts in normal and pathological periodontal wound healing. Oral Dis 24(1-2):26-29. https:// doi.org/10.1111/odi.12773

64. Mokoena DR, Houreld NN, Dhilip Kumar SS, Abrahamse H (2020) Photobiomodulation at $660 \mathrm{~nm}$ stimulates fibroblast differentiation. Lasers Surg Med 52(7):671-681. https://doi.org/10. $1002 / \mathrm{lsm} .23204$

65. Keskiner I, Lutfioğlu M, Aydogdu A, Saygun NI, Serdar MA (2016) Effect of photobiomodulation on transforming growth factor- $\beta 1$, platelet-derived growth factor-BB, and interleukin- 8 release in palatal wounds after free gingival graft harvesting: a randomized clinical study. Photomed Laser Surg 34(6):263-271. https://doi.org/10.1089/pho.2016.4094

66. Sassoli C, Chellini F, Squecco R, Tani A, Idrizaj E, Nosi D, Giannelli M, Zecchi-Orlandini S (2016) Low intensity $635 \mathrm{~nm}$ diode laser irradiation inhibits fibroblast-myofibroblast transition reducing TRPC1 channel expression/activity: new perspectives for tissue fibrosis treatment. Lasers Surg Med 48(3):318-332. https:// doi.org/10.1002/lsm.22441

67. Safavi SM, Kazemi B, Esmaeili M, Fallah A, Modarresi A, Mir M (2008) Effects of low-level He-Ne laser irradiation on the gene expression of IL-1beta, TNF-alpha, IFN-gamma, TGF-beta, bFGF, and PDGF in rat's gingiva. Lasers Med Sci 23(3):331-335. https://doi.org/10.1007/s10103-007-0491-5

68. Mokoena D, Dhilip Kumar SS, Houreld NN, Abrahamse H (2018) Role of photobiomodulation on the activation of the Smad pathway via TGF- $\beta$ in wound healing. J Photochem Photobiol, B 189:138-144. https://doi.org/10.1016/j.jphotobiol.2018.10.011

69. Rai Y, Pathak R, Kumari N, Sah DK, Pandey S, Kalra N, Soni R, Dwarakanath BS, Bhatt AN (2018) Mitochondrial biogenesis and metabolic hyperactivation limits the application of MTT assay in the estimation of radiation induced growth inhibition. Sci Rep 8(1):1531. https://doi.org/10.1038/s41598-018-19930-w

70. Suliman HB, Carraway MS, Welty-Wolf KE, Whorton AR, Piantadosi CA (2003) Lipopolysaccharide stimulates mitochondrial biogenesis via activation of nuclear respiratory factor-1. J Biol Chem 278(42):41510-41518. https://doi.org/10.1074/jbc.M3047 19200

71. Bullon P, Cordero MD, Quiles JL, Morillo JM, del Carmen R-T, Battino M (2011) Mitochondrial dysfunction promoted by Porphyromonas gingivalis lipopolysaccharide as a possible link between cardiovascular disease and periodontitis. Free Radic Biol Med 50(10):1336-1343. https://doi.org/10.1016/j.freeradbiomed. 2011.02.018

72. Phaniendra A, Jestadi DB, Periyasamy L (2015) Free radicals: properties, sources, targets, and their implication in various diseases. Indian J Clin Biochem 30(1):11-26. https://doi.org/10. 1007/s12291-014-0446-0

73. Okada H, Murakami S (1998) Cytokine expression in periodontal health and disease. Crit Rev Oral Biol Med 9(3):248-266. https:// doi.org/10.1177/10454411980090030101

Publisher's note Springer Nature remains neutral with regard to jurisdictional claims in published maps and institutional affiliations. 